\title{
Role of cGMP-Kinase II in the Control of Renin Secretion and Renin Expression
}

\author{
Charlotte Wagner, ${ }^{*}$ Alexander Pfeifer, ${ }^{\ddagger}$ Peter Ruth, ${ }^{\ddagger}$ Franz Hofmann, ${ }^{\ddagger}$ and Armin Kurtz ${ }^{*}$ \\ *Institut für Physiologie I, Universität Regensburg, D-93040 Regensburg, Germany; and ${ }^{\ddagger}$ Institut für Pharmakologie und Toxikologie, \\ Technische Universität München, D-80802 München, Germany
}

\begin{abstract}
To investigate the roles of the cGMP-dependent protein kinases (cGKs) in the control of the renin system, we studied the regulation of renin in cGKI- or cGKII-deficient mice in vivo and in vitro. Renal renin mRNA levels both under stimulatory (low-salt diet plus ramipril) and inhibitory (high-salt diet) conditions were not different between wildtype and $c G K I-/-$ mice, but were significantly elevated in $c G K I I-/-$ mice under all experimental conditions. In primary cultures of renal juxtaglomerular cells (JG) established from wild-type, $c G K I-/-$, and $c G K I I-/-$ mice, the adenylate cyclase activator forskolin stimulated renin secretion similarly in all genotypes tested. 8-bromo-cGMP attenuated basal and forskolin-stimulated renin secretion in cultures from wild-type and $c G K I-/-$, but had no effect in cells isolated from $c G K I I-/-$ mice. Activation of cGKs by 8-bromo-cGMP decreased renin secretion from the isolated perfused rat kidney, independent of prestimulation by $\beta$-adrenoreceptor activation, macula densa inhibition, reduced perfusion pressure, or by a nominally calcium-free perfusate. Taken together, these findings suggest that activation of cGKII has a general inhibitory effect on renin secretion from renal JG cells. (J. Clin. Invest. 1998. 102:1576-1582.) Key words: renin mRNA • juxtaglomerular cell • isolated perfused kidney $\bullet$ cGKII $\bullet$ knockout
\end{abstract}

\section{Introduction}

The synthesis and the secretion of renin from renal juxtaglomerular $(\mathrm{JG})^{1}$ cells, as the main site of renin expression, is controlled by several second messenger pathways. The pathway best established to date is cAMP, which stimulates both the exocytosis of renin as well as renin mRNA levels (1-3). The natural opponent to cAMP in the cellular control of the renin system appears to be a calcium-related pathway that could involve protein kinase $\mathrm{C}$ activity (1-3). There is also evidence that cGMP may participate in the control of the renin system $(2,4,5)$. The precise role of cGMP in this context, however, is

Address all correspondence to Charlotte Wagner Ph. D., Physiologisches Institut, Universität Regensburg, D-93040 Regensburg, Germany. Phone: 49-941-943-2980; FAX: 49-941-943-4315; E-mail: charlotte. schmid@vkl.uni-regensburg.de

Received for publication 19 May 1998 and accepted in revised form 1 September 1998.

1. Abbreviations used in this paper: cGK, cGMP-dependent kinase; $\mathrm{JG}$, juxtaglomerular cell; $\mathrm{NO}$, nitric oxide.

J. Clin. Invest.

(C) The American Society for Clinical Investigation, Inc. 0021-9738/98/10/1576/07 \$2.00

Volume 102, Number 8, October 1998, 1576-1582

http://www.jci.org highly controversial. A review of the effects of factors elevating cGMP levels in JG cells, such as endothelium-derived nitric oxide (NO) or atrial natriuretic peptide, reveals a scatter of contradictory results. Thus, NO has been designated both a stimulator (6-15) and an inhibitor of renin secretion (16-21) in vivo and in vitro. Similar contradictory data-stimulation (2224) and inhibition (25-28) of renin secretion-have been obtained for atrial natriuretic peptide. The data from studies on the effects of stable, membrane-permeable cGMP analogues is more consistent and generally reflect inhibition of renin secretion from isolated perfused kidneys, kidney slices, or isolated JG cells $(18,27,29-32)$. Inhibition of renin secretion by cGMP could, in principle, be mediated by three different cGMP receptors: the cGMP-dependent protein kinases (cGKs), cGMPgated ion channels, or cGMP-regulated phosphodiesterases (33-36). Because commonly used, membrane-permeable, stable cGMP analogues have a high affinity for cGKs, but only a low affinity to cAMP-phosphodiesterases (37), and because so far no evidence exists for cGMP-gated ion channels in JG cells (38), it appears reasonable to assume that the inhibitory effect of cGMP analogues on renin secretion is mediated by cGKs. JG cells contain both cGK subtypes, named cGKI $(39,40)$ and cGKII $(41,42)$ with strikingly different intracellular distributions. Whereas cGKI is localized in the cytosol, cGKII occurs predominantly in association with renin storage granules (43).

In view of the foregoing, the aim of the present study was to examine the roles of the two cGK subtypes in the control of renin secretion by studying the regulation of the renin system in tissues of $c G K I-/-$ and $c G K I I-/-$ mice $(44,45)$, and to establish which of the different pathways regulating renin secretion at the organ level involves negative control by cGKs. To this end, we also studied in more detail the effect of cGK activation on renin secretion stimulated by classic conditions using the isolated perfused rat kidney model.

Our results suggest that cGKII exerts a general negative control function on the renin system both in vivo and in vitro.

\section{Methods}

Animals. The experiments were conducted in 10-16-wk-old $c G K I-/-$ (44) and $c G K I I-/-(45)$ mice. Litter-matched wild-type (+/+) mice were used as controls. Strain background $(\mathrm{C} 57 \mathrm{Bl} / 6 \times 129 \mathrm{~Sv})$ of the $-/-$ and $+/+$ animals were identical. Eight mice of each genotype were assigned to three groups: (a) Control animals received normal chow $(0.6 \% \mathrm{NaCl})$ and remained untreated; $(b)$ Animals with highsalt diet. Mice were maintained for $10 \mathrm{~d}$ on chow balanced in all respects except for a high sodium content ( $4 \% \mathrm{NaCl}$, Altromin); and (c) Animals with low-salt diet and ramipril treatment. Mice were kept on low-salt diet $(0.02 \% \mathrm{NaCl}$, Altromin) for $10 \mathrm{~d}$. For the last $3 \mathrm{~d}$, the converting enzyme inhibitor ramipril $\left(10 \mathrm{mg} \mathrm{kg}^{-1} \mathrm{day}^{-1}\right)$ was given in the drinking water.

At the end of the experiments the animals were killed by decapitation. The kidneys were removed rapidly and frozen in liquid nitrogen. The organs were stored at $-80^{\circ} \mathrm{C}$ until isolation of total RNA, which was extracted from the frozen kidneys as described by Chomczynski and Sacchi (46). 
Determination of renin $m R N A$ by RNase protection assay. Renin mRNA was measured by an RNase protection assay. For detection of preprorenin mRNA, an antisense RNA probe suitable for detecting mRNA levels from the renin-1 gene (ren-1), was generated by in vitro transcription of the plasmid vector pSP73 (Promega-Serva, Heidelberg, Germany), containing a PCR-derived fragment of mouse preprorenin cDNA (47). The 194-bp fragment, amplified by the upstream primer $\left(5^{\prime}\right.$-atg aag ggg gtg ttc tgt ggg gtc- $3^{\prime}$; binding at $810-832$ bp) and the downstream primer (5'-atg cgg gga ggg tgg gca cct g- $3^{\prime}$; binding at 981-1,003 bp), was cloned in a BamHI/EcoRI-digested pSP73 vector using standard protocols. Linearization with HindIII and in vitro transcription with SP6 RNA polymerase yielded a 248-bp fragment. Hybridization, RNase digestion, phenol/chloroform extraction, and acrylamide electrophoresis are described in detail elsewhere (14).

Determination of cytosolic $\beta$-actin by RNase protection assay. The presence of cytosolic $\beta$-actin mRNA was measured by an RNase protection assay. The upstream primer $\left(5^{\prime}\right.$-cca act ggg acg cat g- $3^{\prime}$; binding at $152-168 \mathrm{bp}$ ) and downstream primer (5'-tgg cgt gag gga gag cat-3'; binding at 428-445 bp) were used to amplify a 293-bp fragment of mouse $\beta$-actin cDNA (48). Cloning in a BamHI/EcoRIdigested pSP73 plasmid, linearization with HindIII, and in vitro transcription with SP6 RNA polymerase yielded a 347-bp antisense RNA transcript. $\beta$-actin mRNA was used as a standard RNA for controlling the quality of the RNA preparation. Total RNA $(1 \mu \mathrm{g})$ was hybridized under the conditions described previously (14).

Renin secretion from cultured JG cells. Primary cultures of JG cells were established from wild-type, $c G K I-/-$, and $c G K I I-/-$ mice. The isolation of mouse JG cells has been described in detail elsewhere (32). Renin secretion rates were estimated from the appearance rate of renin in the culture medium. To minimize differences among different cell culture preparations, renin secretion rates were calculated as fractional release of total renin (i.e., renin activity released/[renin activity released + renin activity remaining in the cells]). The generated angiotensin I was determined by radioimmunoassay (Sorin, Biomedica, Düsseldorf, Germany).

Renin secretion from isolated perfused kidneys. Male Sprague-Dawley rats (250-300 g body weight; Indianapolis, IN) having free access to commercial pellet chow and tap water were obtained from the local animal house and used throughout. Preparation and kidney perfusion were performed in a recycling system as described in detail previously (30). After establishing the reperfusion loop, perfusate flow rates usually stabilized within $15 \mathrm{~min}$. Samples for the determination of renin activity were taken at 5-min intervals. Renin secretion rates were calculated from the arterio-venous differences of renin activity and the perfusate flow rate. The perfusate samples were diluted 1:5 in buffer and were incubated for $1.5 \mathrm{~h}$ at $37^{\circ} \mathrm{C}$ with plasma from bilaterally nephrectomized male rats as renin substrate. The generated angiotensin I was determined by radioimmunoassay (Sorin, Biomedica). Five kidneys were used for each experimental protocol.

Statistics. Significance levels between kidneys were calculated with ANOVA and Bonferroni's correction. Student's paired $t$ test was used to calculate levels of significance within individual cell preparations. Student's paired $t$ test was used also to calculate levels of significance within individual kidneys. A $P$ value of 0.05 was considered significant.

\section{Results}

In vivo experiments. To study the possible roles of cGKI and cGKII in the control of the renal renin system in vivo, mice lacking either cGKI or cGKII and the corresponding wild-type controls were subjected to maneuvers either stimulating or inhibiting renal ren-1 mRNA levels determined by specific RNAse protection.

Under a standard salt diet $(0.6 \% \mathrm{NaCl})$, ren- 1 mRNA levels were not different between wild-type and $c G K I-/-$ mice,

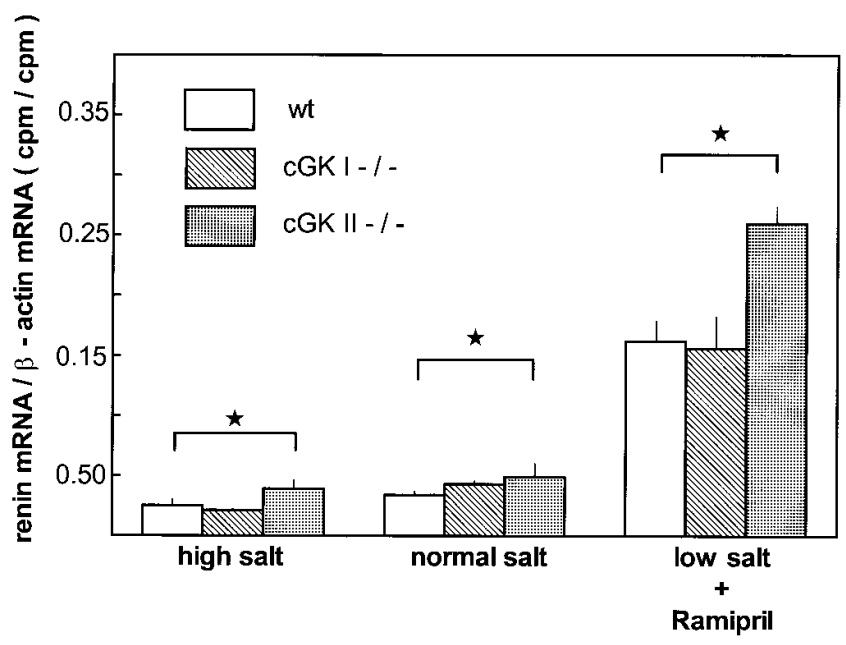

Figure 1. Renin mRNA expression in the kidneys of wild-type mice and in mice lacking the cGMP-dependent kinase, types I or II (cGKI-/- and $c G K I I-/-)$ kept on a normal salt diet, a high-salt diet, or on a low-salt diet plus ramipril. Renin-mRNA values were standardized to $\beta$-actin mRNA, which was not different between the different mouse genotypes, nor between the different treatment groups. Data are means \pm SE of eight mice in each group. ${ }^{*} P<0.05$.

whereas in $c G K I I-/-$ mice, ren-1 mRNA was increased by $\sim 50 \%$ (Fig. 1). A high-salt diet (4\%) for $10 \mathrm{~d}$ decreased renin mRNA significantly to $\sim 50 \%$ of normal in both wild-type and in $c G K I-/-$ mice. Although in the $c G K I I-/-$ mice, renin mRNA levels were also lowered by a high-salt intake, renin mRNA concentrations were still $60 \%$ higher than in wild-type and $c G K I-/-$ mice (Fig. 1). Feeding a low-salt diet $(0.02 \%)$ for $10 \mathrm{~d}$ combined with the ACE inhibitor, ramipril $(10 \mathrm{mg}$ $\mathrm{kg}^{-1} \mathrm{day}^{-1}$ ), for the last $3 \mathrm{~d}$ increased renin mRNA levels significantly by about fivefold compared with normal in both wild-type and $c G K I-/-$ mice, whereas in $c G K I I-/-$ mice, renin mRNA levels were only $\sim 40 \%$ higher than in wildtype and $c G K I-/-$ mice (Fig. 1). Taken together, the regulation of renal renin mRNA was normal in $c G K I-/-$ mice. In $c G K I I-/-$ mice, the regulation of renin mRNA by salt intake was also quite normal, although renin gene expression appeared to be enhanced in proportion under each of the conditions examined.

Experiments with cultured juxtaglomerular cells. To study the effects of the lack cGK on renin release from the JG apparatus, we prepared primary cultures of JG cells from wild-type, $c G K I-/-$, and $c G K I I-/-$ kidneys. The basal renin release rates of JG cells isolated from wild-type and from $c G K I-/-$ mice were similar, whereas that from $c G K I I-/-$ tended to be somewhat higher (Fig. 2). Renin secretion was stimulated similarly in JG cell cultures of all three mouse genotypes by the adenylate cyclase activator forskolin (Fig. 2). Conversely, activation of cGK by 8 -bromo-cGMP $(100 \mathrm{mM})$ attenuated basal and forskolin-induced renin secretion significantly in JG cell from wild-type and $c G K I-/-$ mice, but was without effect in cultures derived from $c G K I I-/-$ mice (Fig. 2). Because the inhibitory effect of 8-bromo-cGMP on renin secretion in wildtype and $c G K I-/-$ cultures could be reversed by higher concentrations of forskolin (Fig. 2), it was of interest to compare the dependency of the inhibitory effect of 8-bromo-cGMP on 


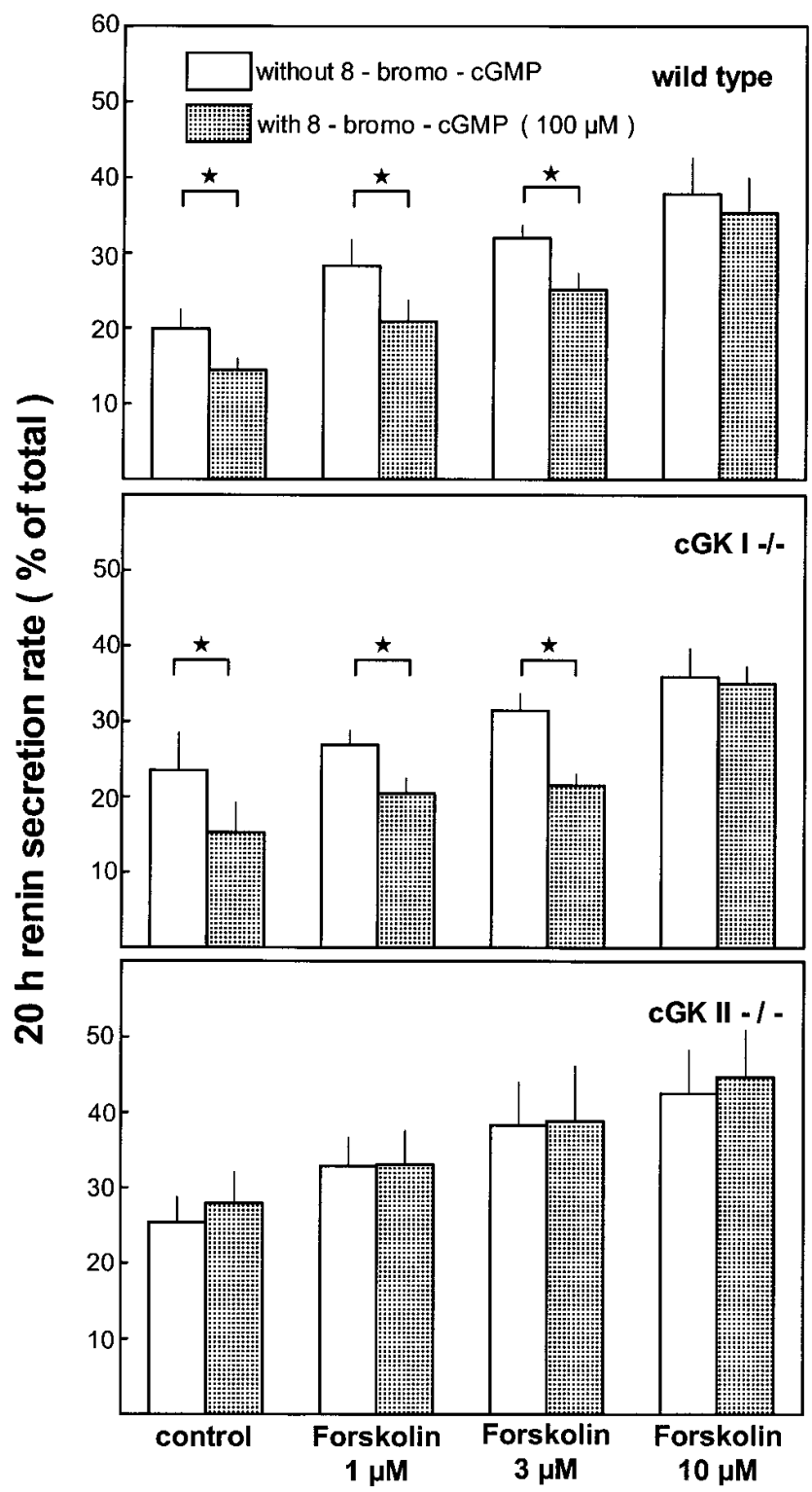

Figure 2. Renin secretion rates from primary cultures of renal JG cells prepared from wild-type, $c G K I-/-$, and $c G K I I-/-$ mice. Renin secretion rates were determined over a 20 -h incubation period with vehicle, increasing doses of forskolin $(1,3$, and $10 \mu M)$ and 8-bromo-cGMP $(100 \mu M)$. Renin secretion rates are given as fractional release of total renin activity stored in the cells. Data are means \pm SE of five experiments, each done with different cell preparations. Each experiment represents the mean of quadruplicate culture wells. $* P<0.05$. Total renin activity of the cultures was $29 \pm 6$, $32 \pm 8$, and $38 \pm 6 \mathrm{mg}$ ANGI $\times \mathrm{h}^{-1} \times \mathrm{mg}$ protein ${ }^{-1}$ for cells isolated from wild-type, $c G K I-/-$, and $c G K I I-/-$ mice, respectively.

the concentration of forskolin between wild-type, $c G K I-/-$, and $c G K I I-/-$ cultures. As shown in Fig. 2, an inhibitory effect of 8-bromo-cGMP in $c G K I I-/-$ cultures was absent in the whole concentration range of forskolin used in this study.

Because the foregoing observations strongly imply an inhibitory effect of cGKII on the renin system, it appeared of further interest to investigate which of the multiple pathways involved in the control of renin secretion on the organ levels

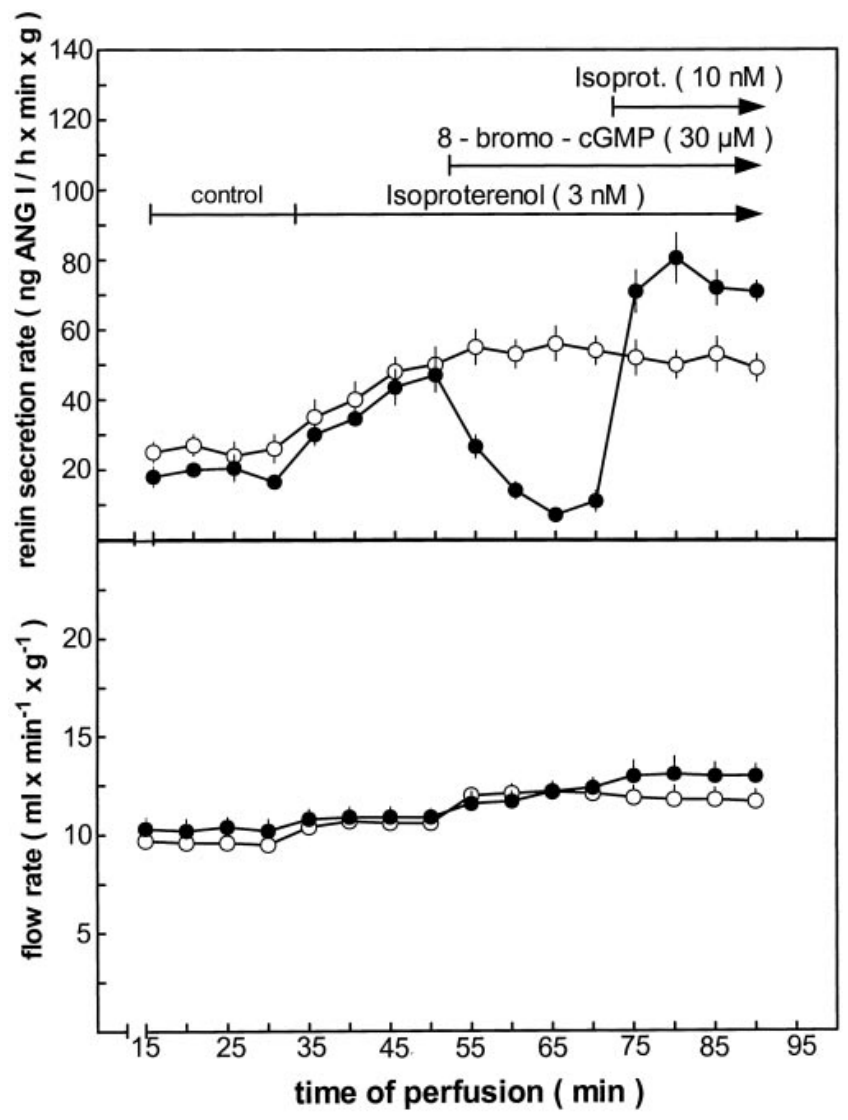

Figure 3. Effects of isoproterenol (3 and $10 \mathrm{nM})$ and of 8-bromocyclic GMP $(30 \mu \mathrm{M})$ on renin secretion and renal flow rate from isolated rat kidneys perfused at $100 \mathrm{mmHg}$ (closed circle). Samples were taken at 5-min intervals during the different experimental periods, the duration of which is indicated in the upper part of the figure. Time control without 8-bromo-cGMP and isoproterenol (10 $\mathrm{nM})$ perfusion (open circle). For determination of significant differences, renin secretion rates obtained within a certain experimental period of each kidney were taken together and averaged. The experimental protocols were run with five different kidneys. Data are means \pm SE.

involves cGKII. This question was addressed in experiments in the isolated perfused rat kidney.

Experiments with isolated perfused kidneys. As shown in Fig. 3, the $\beta$-adrenoreceptor activator isoproterenol $(3 \mathrm{nM})$ led to a sustained, threefold stimulation of renin secretion $(P<$ $0.05)$. In the presence of 8-bromo-cGMP $(30 \mu \mathrm{M})$, renin secretion rates significantly decreased $(P<0.05)$ and returned to near basal values. Increasing the concentration of isoproterenol from 3 to $10 \mathrm{nM}$ in the presence of 8-bromo-cGMP again increased renin secretion rates $(P<0.05)$ (Fig. 3). The renal blood flow in this experiment showed a slight but significant increase when 8-bromo cGMP was added to the perfusate (Fig. 3, bottom).

Renin secretion is also controlled by an inhibitory signal from the macula densa cells, which generate this signal in proportion to their salt transport rate $(49,50)$. Inhibition of salt transport at the macula densa by the loop diuretic bumetanide $(100 \mu \mathrm{M})$ doubled renin secretion $(P<0.05)$ (Fig. 4). In the presence of 8-bromo-cGMP, renin secretion rates decreased $(P<0.05)$ and returned to slightly subnormal values, and in- 


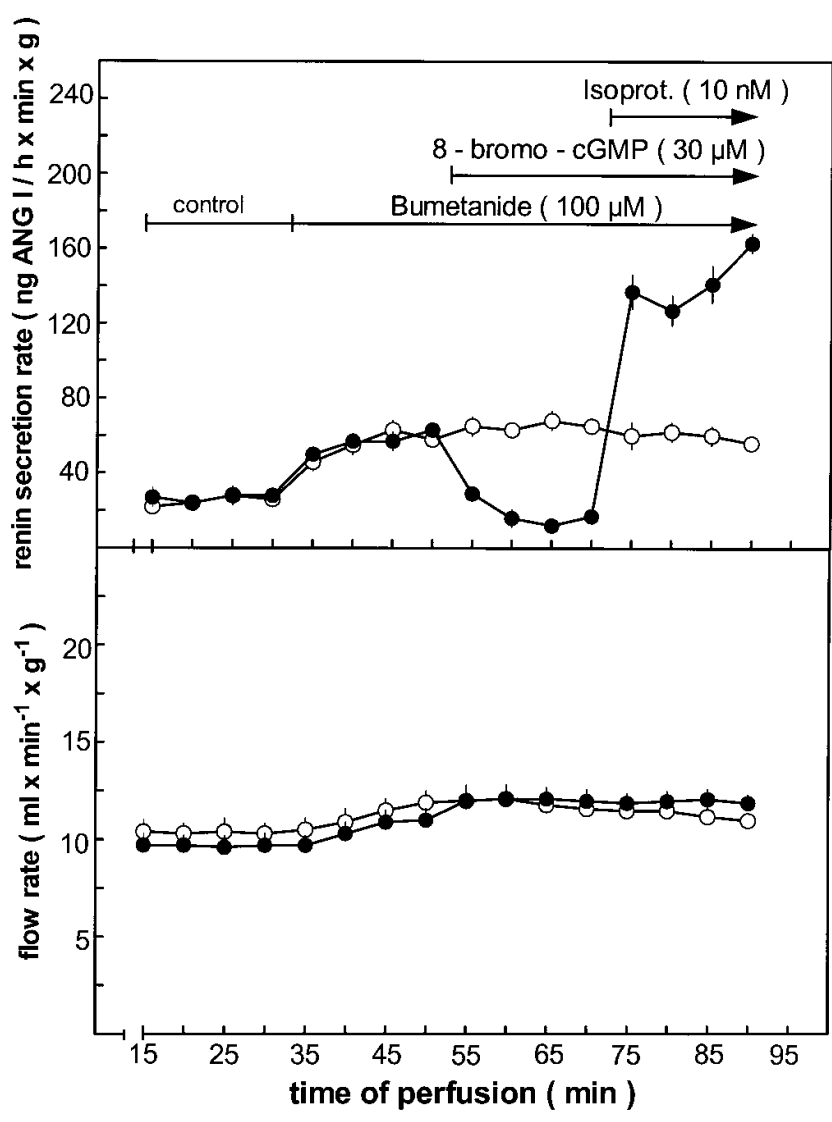

Figure 4. Effect of bumetanide $(100 \mu \mathrm{M}), 8$-bromo-cGMP $(30 \mu \mathrm{M})$, and of isoproterenol $(10 \mathrm{nM})$ on renin secretion and renal flow rate from isolated rat kidneys perfused at $100 \mathrm{mmHg}$ (closed circle). Samples were taken at 5-min intervals during the different experimental periods, the duration of which is indicated in the upper part of the figure. Time control without 8-bromo-cGMP and isoproterenol $(10 \mathrm{nM})$ perfusion (open circle). For determination of significant differences, renin secretion rates obtained within a certain experimental period of each kidney were taken together and averaged. The experimental protocols were run with five different kidneys. Data are means \pm SE.

creased $(P<0.05)$ again when isoproterenol $(10 \mathrm{nM})$ was added to the perfusate in the presence of bumetanide and 8-bromo-cGMP (Fig. 4). Again, renal blood flow increased slightly $(P<0.05)$ in the presence of 8 -bromo-cGMP (Fig. 4, bottom).

Renin secretion is also under the control of the renal perfusion pressure, such that a fall of the perfusion pressure enhances renin secretion (1). As shown in Fig. 5, a reduction of the perfusion pressure from the standard pressure of 100 $\mathrm{mmHg}$ to $40 \mathrm{mmHg}$ led to a significant decrease of renal flow rate and a 3.5 -fold increase $(P<0.05)$ of renin secretion. 8-bromo-cGMP $(30 \mu \mathrm{M})$ attenuated $(P<0.05)$ this stimulation by low pressure to an about twofold stimulation (versus basal) of renin secretion (Fig. 5). Isoproterenol (10 $\mathrm{nM})$ again increased $(P<0.05)$ renin secretion to $\sim 10$ times above basal values in the presence of 8-bromo-cGMP at a perfusion pressure of $40 \mathrm{mmHg}$ (Fig. 5).

Calcium is thought to exert an inhibitory effect on renin secretion, and lowering the extracellular calcium concentration increases renin secretion in a variety of experimental prepara-

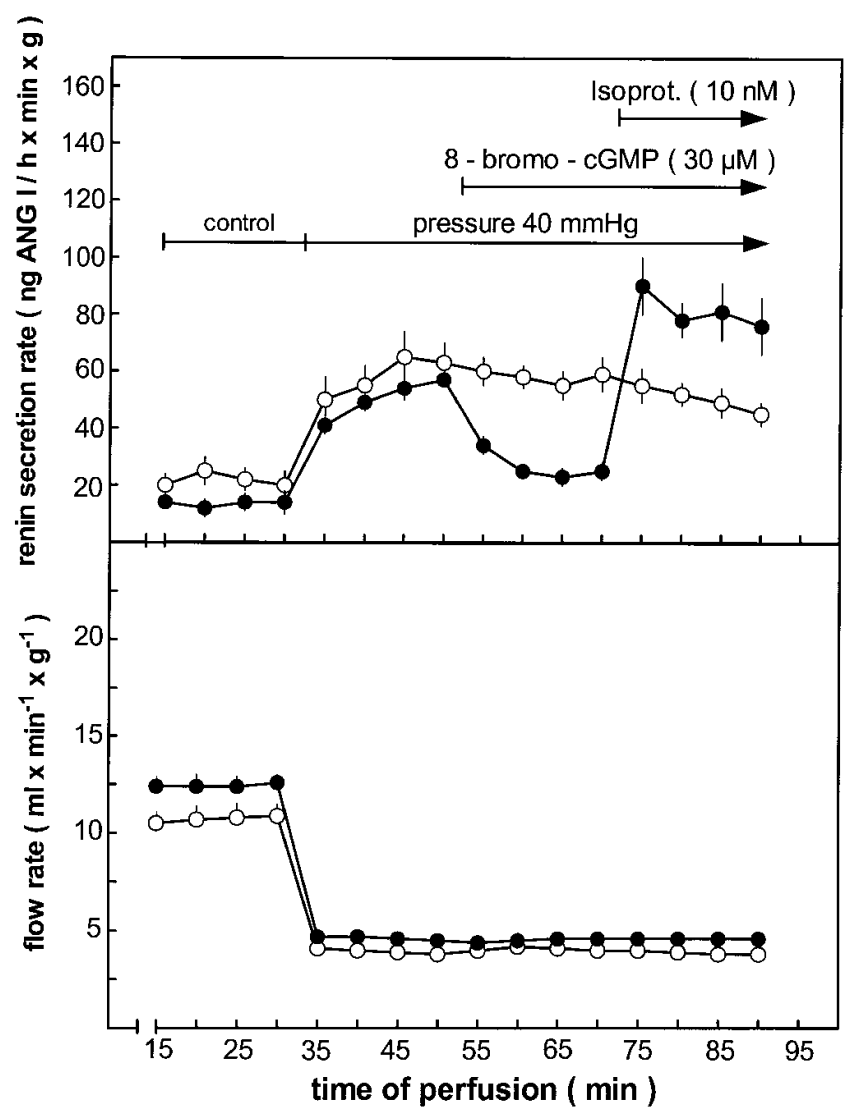

Figure 5. Effect of 8-bromo-cGMP $(30 \mu \mathrm{M})$ or isoproterenol $(10 \mathrm{nM})$ on renin secretion and renal flow rate in isolated rat kidneys perfused at $40 \mathrm{mmHg}$ (closed circle). Samples were taken at 5-min intervals during the different experimental periods, the duration of which is indicated in the upper part of the figure. Time control without 8 -bromo-cGMP and isoproterenol $(10 \mathrm{nM})$ perfusion (open circle). For determination of significant differences, renin secretion rates obtained within a certain experimental period of each kidney were taken together and averaged. The experimental protocols were run with five different kidneys. Data are means \pm SE.

tions (1). In our experiments, we lowered the extracellular calcium by using a nominally calcium-free perfusate supplemented with $0.5 \mathrm{mM}$ EGTA, a calcium chelator. As shown in Fig. 6, lowering the extracellular calcium concentration led to a fourfold stimulation $(P<0.05)$ of renin secretion (Fig. 6) and simultaneously to an increased blood flow. 8-bromo-cGMP again reversed the renin stimulation $(P<0.05)$, and further addition of isoproterenol to the low-calcium, 8-bromo-cGMPcontaining perfusate reestablished the stimulation $(P<0.05)$ (Fig. 6).

\section{Discussion}

Against a background of indirect evidence that cGK activity may exert an inhibitory control on the renin system, the aim of this study was to establish and characterize the specific role of the different cGK subtypes. Our findings now show that the regulation of the renal renin system, as reflected by renal renin mRNA levels, is completely unobtrusive in mice lacking cGKI, suggesting that cGKI either plays no major role in the control 


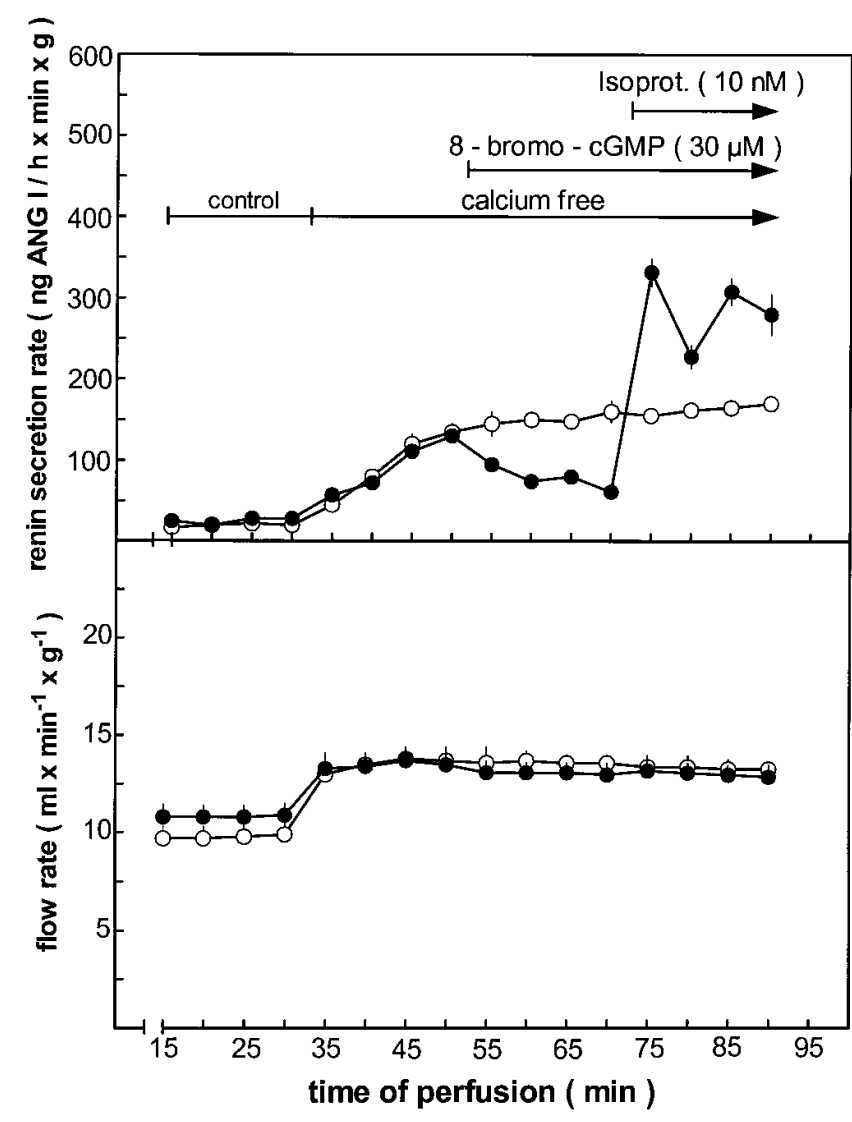

Figure 6. Effect of calcium-free perfusate, 8-bromo-cGMP $(30 \mu \mathrm{M})$ and isoproterenol $(10 \mathrm{nM})$ on renin secretion and renal flow rate from isolated rat kidneys perfused at $100 \mathrm{mmHg}$ (closed circle). Samples were taken at 5-min intervals during the different experimental periods, the duration of which is indicated in the upper part of the figure. Time control without 8-bromo-cGMP and isoproterenol (10 nM) perfusion (open circle). For determination of significant differences, renin secretion rates obtained within a certain experimental period of each kidney were taken together and averaged. The experimental protocols were run with five different kidneys. Data are means \pm SE.

of the renin system or that a potential effect induced by the lack of cGKI is completely compensated by other mechanisms. Because the regulation of renin secretion in isolated JG cells taken from $c G K I-/-$ mice was also quite normal, it appears more reasonable to assume that cGKI plays, if at all, only a minor role in the renin system. In contrast, the inhibitory effect of cGK stimulation on renin secretion was completely absent in $\mathrm{JG}$ cells isolated from $c G K I I-/-$ mice. In vivo the gain of renin expression was significantly increased in $c G K I I-/-$ mice, whereas the principal regulation by salt or angiotensin II was maintained. These findings are compatible with the idea that cGKII exerts a more general inhibitory effect on the renin system and which is also active under in vivo conditions. Our findings, moreover, suggest that the inhibitory effect of cGKII activation is not irreversible but may be overcome by strong adenylate cyclase activation. cGKs exhibit a different cellular distribution in JG cells. Whereas cGKI is found in the cytosol, cGKII is associated with renin storage granules (43). This unequal distribution of cGKs within JG cells may explain why only cGKII plays an active role in the inhibition of the renin system (see below).
To obtain further information on the relevance of cGKIImediated inhibition of renin secretion, we studied the effect of cGK activation on renin secretion prestimulated by different physiological maneuvers. cGK activation rather unselectively attenuated renin secretion stimulated by $\beta$-adrenoreceptor activation, macula densa inhibition, the renal baroreceptor mechanism, and reduction of the extracellular calcium concentration. In all instances, renin secretion could again be increased by strong adenylate cyclase activation by a higher concentration of isoproterenol, findings quite consistent with those made in isolated JG cells. Supportive evidence for our conclusions further exists from a study showing that G-kinase activator 8 p-CTP-cGMP inhibited renin secretion from microdissected renal afferent arterioles and the G-kinase inhibitor Rp-8 p-CTP-cGMP attenuated this inhibition (51).

Because cGK activation also inhibited renin secretion induced by low extracellular calcium, a condition for example under which the inhibitory effect of angiotensin II on renin secretion is completely abolished (52), it may be inferred that the inhibitory effect of cGKII is not mediated by the inhibitory calcium pathway controlling renin secretion and renin synthesis. Further studies will therefore be necessary to define the inhibitory effect of cGKII at the level of the JG cell. In view of the fact that cGKII, but not cGKI, colocalizes with renin storage granules (43), and that cGKII activation apparently exerts a general inhibitory effect on the exocytosis of renin, one may speculate that cGKII acts by inducing events in renin secretory granules that impair the exocytotic event. According to the chemiosmotic theory of renin secretion, swelling of renin storage vesicles induced by $\mathrm{KCl}$ influx is a crucial event for the initiation of exocytosis (53). Because the swelling of renin storage vesicle has been hypothesized to be controlled by protein kinase-mediated events, it is conceivable that cGKII is involved in this interplay of protein kinases. In accordance with such a concept are also previous findings that cGKs can influence the activity of protein phosphatases (54-58), and of potassium and/or chloride channels (54-59). Whatever the intracellular mode of action of cGKII in JG cells may be, the present data imply that activation of cGKII by cGMP in JG cells inhibits renin secretion. At first glance, this conclusion is not free from contradiction because, as mentioned above, native stimulators of cGMP formation in JG cells, such as NO or ANP, reportedly stimulate renin secretion. We have shown that a stimulatory cGMP effect on renin secretion is causally related to inhibition of cAMP degradation (60). Thus, cGMP appears to have a dual effect on renin secretion, namely, stimulation via a linkage to the cAMP pathway and inhibition via cGKII activation. This raises the question about the determinants of the stimulatory or the inhibitory cGMP pathway. The majority of investigations report that the overall effect of cGMP in vivo is stimulation, suggesting that the cAMP pathway normally predominates. Because the inhibitory effect of membrane permeable cGMP analogues on renin secretion from JG cells can be reversed by strong adenylate cyclase activity (Fig. 2), it appears as if the inhibitory pathway could be masked by high cAMP efficacy. Conversely, in experiments with isolated perfused kidneys, NO donors have been shown to exert an intensified inhibitory effect on renin secretion in presence of calcium-mobilizing factors such as angiotensin II (30), suggesting that states of enhanced cytosolic calcium and protein kinase $\mathrm{C}$ activity impair the renin secretion via cAMP pathway. Taken together, it appears as if the momentary efficacy of cAMP or 
calcium and protein kinase $\mathrm{C}$ systems determines whether the stimulatory or the inhibitory pathway predominates, thus, controlling the overall effect of cGMP on the renin system.

\section{Acknowledgments}

The skillful assistance provided by K.H. Götz, M. Hamann, and M.L. Schweiger is gratefully acknowledged. We also thank K. Dörr, M. Wöckner, and S. Kamm for excellent technical assistance.

This study was supported by grants from DFG and Fonds der Chemie.

\section{References}

1. Hackenthal, E., M. Paul, D. Ganten, and R. Taugner. 1990. Morphology, physiology and molecular biology of renin secretion. Physiol. Rev. 70:10671116.

2. Kurtz, A. 1989. Cellular control of renin secretion. Rev. Physiol. Biochem. Pharmacol. 113:2-40.

3. Della Bruna, R., A. Kurtz, and K. Schricker. 1996. Regulation of renin synthesis in the juxtaglomerular cells. Curr. Op. Nephrol. Hypertens. 5:16-19.

4. Reid, I.A., and Y.J. Chiu. 1995. Nitric oxide and the control of renin secretion. Fundam. Clin. Pharmacol. 9:309-323.

5. Romero, J.C., V. Lahera, M.G. Salom, and M.L. Biondi. 1992. Role of the endothelium-dependent relaxing factor nitric oxide on renal function. $J$. Am. Soc. Nephrol. 2:1371-1387.

6. Beierwaltes, W.H. 1995. Selective neuronal nitric oxide synthase inhibition blocks furosemide-stimulated renin secretion in vivo. Am. J. Physiol. 269: F134-F139.

7. Deng, X., W.J. Welch, and C.S. Wilcox. 1994. Renal vasoconstriction during inhibition of NO synthase: effects of dietary salt. Kidney Int. 46:639-646.

8. Gardes, J., J.M. Poux, M.F. Gonzalez, F. Alhenc-Gelas, and J. Menard. 1992. Decreased renin release and constant kallikrein secretion after injection of L-NAME in isolated perfused rat kidney. Life Sci. 50:987-993.

9. Hackenthal, E., K. Münter, and S. Fritsch. 1994. Role of nitric oxide in the control of renin release from normal and hydronephrotic rat kidney. Endothelium. 2:229-237.

10. Johnson, R.A., and R.H. Freeman. 1994. Renin release in rats during blockade of nitric oxide synthesis. Am. J. Physiol. 266:R1723-R1729.

11. Naess, P.A., G. Christensen, K.A. Kirkeboen, and F. Kiil. 1993. Effect on renin release of inhibiting renal nitric oxide synthesis in anaesthetized dogs. Acta Physiol. Scand. 148:137-142.

12. Persson, P.B., J.E. Baumann, H. Ehmke, E. Hackenthal, H.R. Kirchheim, and B. Nafz. 1993. Endothelium-derived NO stimulates pressure-dependent renin release in conscious dogs. Am. J. Physiol. 264:F943-F947.

13. Scholz, H., and A. Kurtz. 1993. Endothelium derived relaxing factor is involved in the pressure control of renin secretion from the kidneys. J. Clin. Invest. 91:1088-1094.

14. Schricker, K., I. Hegyi, M. Hamann, B. Kaissling, A. Kurtz. 1995. Tonic stimulation of renin gene expression by nitric oxide is counteracted by tonic inhibition through angiotensin II. Proc. Natl. Acad. Sci. USA. 92:8006-8010.

15. Yamada, S.S., A.L. Sasaki, C.K. Fujihara, D.M. Malheiros, G. De Nucci, and R. Zatz. 1996. Effect of salt intake and inhibitor dose on arterial hypertension and renal injury induced by chronic nitric oxide blockade. Hypertension. 27:1165-1172.

16. Beierwaltes, W.H., and O.A. Carretero. 1992. Nonprostanoid endothelium-derived factors inhibit renin release. Hypertension. 19:II68-II73.

17. Fujihara, C.K., S.M. Michellazzo, G. De-Nucci, and R. Zatz. 1994. Sodium excess aggravates hypertension and renal parenchymal injury in rats with chronic NO inhibition. Am. J. Physiol. 266:F697-F705.

18. Greenberg, S.G., X.R. He, J.B. Schnermann, and J.P. Briggs. 1995. Effect of nitric oxide on renin secretion. I. Studies in isolated juxtaglomerular granular cells. Am. J. Physiol. 268:F948-F952.

19. Jover, B., A. Herizi, F. Ventre, M. Dupont, and A. Mimran. 1993. Sodium and angiotensin in hypertension induced by long-term nitric oxide blockade. Hypertension. 21:944-948.

20. Schnackenberg, C.G., B.L. Tabor, M.H. Strong, and J.P. Granger. 1997. Inhibition of intrarenal NO stimulates renin secretion through a macula densamediated mechanism. Am. J. Physiol. 272:R879-R886.

21. Vidal, M.J., J.C. Romero, and P.M. Vanhoutte. 1988. Endotheliumderived relaxing factor inhibits renin release. Eur. J. Pharmacol. 149:401-402.

22. Ehmke, H., P.B. Persson, A. Just, B. Nafz, M. Seyfarth, E. Hackenthal, and H.R. Kirchheim. 1992. Physiological concentrations of ANP exert a dual regulatory influence on renin release in conscious dogs. Am. J. Physiol. 263: R529-R536.

23. Hackenthal, E., R.E. Lang, and C.P. Bührle. 1985. Atrial natriuretic factor stimulates renin release from the isolated rat kidney. J. Hypertens. 3:S323S325.
24. Takagi, M., R. Franco-Saenz, and P.J. Mulrow. 1988. Effect of atrial natriuretic peptide on renin release in a superfusion system of kidney slices and dispersed juxtaglomerular cells. Endocrinology. 122:1437-1442.

25. Antonipillai, I., J. Vogelsang, and R. Horton. 1986. Role of atrial natriuretic factor in renin release. Endocrinology. 119:318-322.

26. Henrich, W.L., E.A. McAllister, P.B. Smith, J. Lipton, and W.B. Campbell. 1987. Direct inhibitory effect of atriopeptin III on renin release in primate kidney. Life Sci. 41:259-264.

27. Kurtz, A., R. Della Bruna, J. Pfeilschifter, R. Taugner, and C. Bauer. 1986. Atrial natriuretic peptide inhibits renin release from isolated renal juxtaglomerular cells by a cGMP mediated process. Proc. Natl. Acad. Sci. USA. 83 4769-4773.

28. Obana, K., M. Naruse, K. Naruse, H. Sakurai, H. Demura, T. Inagami, and K. Shizume. 1985. Synthetic rat atrial natriuretic factor inhibits in vitro and in vivo renin secretion in rats. Endocrinology. 117:1282-1284.

29. Henrich, W.L., E.A. McAllister, P.B. Smith, and W.B. Campbell. 1988. Guanosine 3', 5' -cyclic monophosphate as a mediator of inhibition of renin release. Am. J. Physiol. 255:F474-F478.

30. Kurtz, A., K.H. Götz, M. Hamann, M. Kieninger, and C. Wagner. 1998. Stimulation of renin secretion by NO donors is related to the cAMP pathway. Am. J. Physiol. 274:F709-F712.

31. Noble, A.R., Abu-Kishk, M.A. Dálioa, B.C. Williams, and D.J. Lush. 1994. Cyclic GMP-linked pathway for renin secretion. Kidney Int. 64:15881590 .

32. Schricker, K., and A. Kurtz. 1993. Liberators of NO exert a dual effect on renin secretion from isolated mouse renal juxtaglomerular cells. Am. J. Physiol. 265:F180-F186.

33. Hofmann, F., W. Dostmann, A. Keilbach, W. Landgraf, and P. Ruth. 1992. Structure and physiological role of cGMP-dependent protein kinase. Biochim. Biophys. Acta. 1135:51-60.

34. Lincoln, T.M., and T.L. Cornwell. 1994. Intracellular cGMP receptor proteins. FASEB (Fed. Am. Soc. Biol.) J. 7:328-338.

35. Beavo, J.A. 1995. Cyclic nucleotide phosphodiesterases:functional implications of multiple isoforms. Physiol. Rev. 75:725-748.

36. Biel, M., X. Zong, and F. Hofmann. 1995. Molecular diversity of cyclic nucleotide-gated cation channels. Naunyn-Schmiedeberg's Arch. Pharmacol. 353:1-10.

37. Butt, E., C. Nolte, S. Schulz, J. Beltman, J.A. Beavo, B. Jastorff, and U. Walter. 1992. Analysis of the functional role of cGMP-dependent protein kinase in intact human platelets using a specific activator 8-para-chlorophenylthio-cGMP. Biochem. Pharmacol. 12:2591-2600.

38. Kurtz, A. 1997. Membrane and secretory properties of renal juxtaglomerular granular cells. Clin. Exp. Pharmacol. Physiol. 24:536-540.

39. Wernet, W., V. Flockerzi, and F. Hofmann. 1989. The CDNA of the two isoforms of bovine cGMP-dependent protein kinase. FEBS Lett. 251:191-196.

40. Sandberg, M., V. Natatajan, I. Ronander, D. Kalderon, U. Walter, S. Lohmann, and T. Jahnsen. 1989. Molecular cloning and predicted full-length amino acid sequence of the type I $\beta$ isozyme of cGMP-dependent protein kinase from human placenta. FEBS Lett. 255:321-329.

41. Uhler, M. 1993. Cloning and expression of a novel cyclic GMP-dependent protein kinase from mouse brain. J. Biol. Chem. 268:13586-13591.

42. Jarchau, T., C. Häusler, T. Market, D. Pöhler, I. Vandekerckhove, H.R. De Jonge, S. Lohmann, and U. Walter. 1994. Cloning, expression, and in situ localization of rat intestinal cGMP-dependent protein kinase II. Proc. Natl. Acad. Sci. USA. 91:9426-9430.

43. Gambaryan, S., C. Hausler, T. Markert, D. Pöhler, T. Jarchau, U. Walter, W. Haase, A. Kurtz, and S.M. Lohmann. 1996. Expression of type II cGMP-dependent protein kinase in rat kidney is regulated by dehydration and correlated with renin gene expression. J. Clin. Invest. 98:662-670.

44. Pfeifer, A., P. Klatt, S. Massberg, L. Ny, M. Sausbier, C. Hirneib, G.X. Wang, M. Korth, A. Aszodi, K.E. Anderson, E. Krombach, A. Mayerhofer, P. Ruth, R. Fässler, and F. Hofmann. 1998. Defective smooth muscle regulation in cGMP kinase I-deficient mice. EMBO (Eur. Mol. Biol. Organ.) J. 17:3045-3051.

45. Pfeifer, A., A. Aszodi, U. Seidler, P. Ruth, F. Hofmann, and R. Fässler. 1996. Intestinal secretory defects and dwarfism in mice lacking cGMP dependent protein kinase II. Science. 274:2082-2086.

46. Chomczynski, P., and N. Sacchi. 1987. Single step method of RNA isolation by acid guanidinium thiocyanate-phenol-chloroform extraction. Anal. Biochem. 62:156-159.

47. Kim, W.S., K. Murakami, and K. Nakayama. 1989. Nucleotide sequence of a cDNA coding for mouse Ren1 gene. Nucleic Acids Res. 17:9480.

48. Alonso, S., A. Minty, Y. Bourlet, and M. Buckingham. 1986. Comparison of three actin-coding sequences in the mouse: evolutionary relationships between the actin genes of warm-blooded vertebrates. J. Mol. Evol. 23:11-22.

49. Briggs, J.P., and J. Schnermann. 1996. Whys and wherefores of juxtaglomerular apparatus function. Kidney Int. 49:1724-1726.

50. Skott, O., and J.P. Briggs. 1987. Direct demonstration of macula densa mediated renin release. Science. 237:1618-1620.

51. Gambaryan, S., C. Wagner, A. Smolenski, U. Walter, W. Poller, W Haase, A. Kurtz, and S. Lohmann. 1998. Endogenous or overexpressed cGMdependent protein kinases inhibit cAMP-dependent renin release from rat isolated perfused kidney, microdissected glomeruli, and isolated juxtaglomerular 
cells. Proc. Natl. Acad. Sci. USA. 95:9003-9008.

52. Scholz, H., M. Hamann, K.H. Götz, and A. Kurtz. 1994. Role of calcium ions in the pressure control of renin secretion from the kidneys. Pflügers Arch. 428:173-178.

53. King, J.A., D.J. Lush, and J.C. Fray. 1993. Regulation of renin processing and secretion: chemiosmotic control and novel secretory pathway. Am. J. Physiol. 265:C305-C320.

54. Sansom, S.C., J.D. Stock, D. Hall, and B. Williams. 1997. Regulation of large calcium-activated potassium channels by protein phosphatase 2A. J. Biol. Chem. 272:9902-9906.

55. Wang, X., and P.J. Robinson. 1997. Cyclic GMP-dependent protein kinase and cellular signaling in the nervous system. J. Neurochem. 68:443-456.

56. Zhou, X.B., P. Ruth, J. Schlossmann, F. Hofmann, and M. Korth. 1996. Protein phosphatase 2A is essential for the activation of Ca21-activated K1 currents by cGMP-dependent protein kinase in tracheal smooth muscle and Chi- nese hamster ovary cells. J. Biol. Chem. 271:19760-19767.

57. Sugimoto, T., M. Haneda, M. Togawa, M. Isono, T. Shikano, S. Araki, T. Nakagawa, A. Kashiwagi, K.L. Guan, and R. Kikkawa. 1996. Atrial natriuretic peptide induces the expression of MKP-1, a mitogen-activated protein kinase phosphatase, in glomerular mesangial cells. J. Biol. Chem. 271:544-547.

58. White, R.E., A.B. Lee, A.D. Shcherbatko, T.M. Lincoln, A. Schonbrunn, and D.L. Armstrong. 1993. Potassium channel stimulation by natriuretic peptides through cGMP-dependent dephosphorylation. Nature. 361:263-266.

59. French, P.J., J. Bijman, M. Edixhoven, B. Vaandrager, B.J. Scholte, S.M. Lohmann, A.C. Nairn, and H.R. de-Jonge. 1995. Isotype-specific activation of cystic fibrosis transmembrane conductance regulator-chloride channels by cGMP-dependent protein kinase II. J. Biol. Chem. 270:26626-26631.

60. Kurtz, A., K.H. Götz, M. Hamann, and C. Wagner. 1998. Stimulation of renin secretion by nitric oxide is mediated by phosphodiesterase 3. Proc. Natl. Acad. Sci. USA. 95:4743-4747. 